BOJAN BEŠKOVNIK, Ph.D.

E-mail: bojan.beskovnik@intereuropa.si

Intereuropa, Globalni logistični servis, d.d.

Vojkovo nabrežje 32, SI-6000 Koper, Republic of Slovenia

LIVIO JAKOMIN, Ph.D.

E-mail: livio.jakomin@gmail.com

Strma pot 11, SI-6320 Portorož, Republic of Slovenia
Transport Logistics

Review

Accepted: July 23, 2009

Approved: Mar. 19, 2010

\title{
CHALLENGES OF GREEN LOGISTICS IN SOUTHEAST EUROPE
}

\begin{abstract}
This paper describes the trends towards green logistics in global aspect and challenges of adopting green logistics in the region of Southeast Europe. Modern logistics with supply chain management is experiencing a period of important evolution. From reversible logistics, we came to green logistics, which is a wider concept of environmentally friendly thinking. Reverse logistics includes processes of movements and transportation of waste from users to recycling plants; meanwhile, green logistics deals also with environmental issues such as pollution and environmental degradation caused by improper logistics processes and utilisation of old and environmentally unfriendly transport technology. The case of Southeast Europe was analysed, and in this context, a development model for green logistics implementation was proposed. A vast number of different challenges in the logistics sector are still open in this region; therefore, systematic analyses and proposals should be subject of additional scientific work in the logistics sector. All parties, including manufacturing industry, logistics providers and governments should take an active part in such researches, as the pressure from green thinking will become even stronger in the coming period.
\end{abstract}

\section{KEY WORDS}

reverse logistics, green logistics, logistics providers, Southeast Europe, green logistics model

\section{INTRODUCTION}

Logistics can be defined as a tool for moving raw materials, goods and people to the right place at the desired time. Consequently, logistics is an important function and element of modern transport systems, not only at a national level, but also in a wider global context. It is obvious that the expansion of logistics was supported by globalization, decentralization of production and development of supply chain concepts.

The intensive logistics development, namely, was reached in the second part of the $20^{\text {th }}$ century, when the all-important global enterprises recognized the optimization potentials in time and costs with the right use of logistics basis. Today we have logistics concepts in every sphere of national society and economy. Time and cost elements became important factors, in order to reach added value in all segments of daily life and this is even more evident in the actual financial and economic situation all over the globe.

Fast technological development and the necessity for new transport concepts lead to an unbalanced development. The ecological aspect, namely, was not taken into consideration, as it was not the key element in the social environment. During the last two to three decades, the ecological awareness increased drastically, and it reached satisfactory levels in the developed economies. According to BearingPoint research, globally, 35\% of companies say that they have incorporated the Green Supply Chain strategy in the company's vision. Only half of the companies that show high concern for environmental issues have actually taken account of this in the management of their Supply Chain. The bigger companies have the greater interest in the Green Supply Chain, because $54 \%$ of companies with turnover in excess of 1 billion dollars claim to have established a Green Supply Chain, but this percentage drops to $29 \%$ for companies with a turnover of less than 100 million dollars [1]. According to Eye for transport survey the green issues in the European companies have already started to play an important role in the companies' overall business strategy. Sixty-seven per cent of executives questioned in Europe believed that green issues are important to their company's strategy [2].

On the other hand, in the areas with underdeveloped and poorer economies the "green" awareness is still not present. The main reason lies in the limited financial funds which are necessary to be utilized in manufacturing processes, and in use of modern transportation and handling means. However, it is an inevitable global trend to develop and adopt the concepts of green logistics and those regions will be forced in the near future to use "green" technology and think 
"green" at every level of society, especially in the production and transport sector.

\section{GREEN LOGISTICS}

Modern logistics consists of some crucial elements and actions, which must be consecutively used and adequately combined to achieve the logistics optimum. This optimum can be expressed in cost, time or energy savings. Modern means of transport, manipulation equipment, modern warehouses and concepts as just-in-time and door-to-door are key elements of modern logistics. Combining all elements is an issue of supply chain management, which starts in the production and ends on the retailer's shelf. This was a traditional logistics concept, which seeks to organize forward distribution. With the development of environmental consideration and needs for recycling processes, a completely new sub-sector of logistics appeared: reverse logistics. Reverse logistics consists of reverse distribution and involves transport of used materials and movement of waste.

\subsection{From logistics to green logistics}

Logistics is one of the crucial competitive factors in developed countries. Thus, the modern logistics is oriented to more and more pretentious users and final goods consumers. Consequently, logistics is under constant pressure to seek new ways of optimization and customer satisfaction. Reverse logistics is one of the results of increased demands and needs from different levels of society. Environmental pressure became very strong two decades ago, as the environmental degradation became evident through CFCs, acid rains and global warming.

In the early 1990s reverse logistics became a society obligation in the developed countries. Logistics experts produced a lot of different studies, reports and opinions at that time. Namely Tanja [3] and Murphy [4] exposed how the environment issues could be incorporated in the logistics sector. This new logistics basis was placed as logistics entered in the sector of collecting waste and recycling.

Fundamental actions in the late nineties incorporated reverse logistics as an equal element of the entire logistics. Moreover, it was a starting point of development of green logistics, which is even a wider concept than reverse logistics. Reverse logistics includes processes of movements and transportation of waste from the users to recycling plants. The overall reverse logistics activities can be divided into four main groups: 1. collection, 2. inspection, selection and sorting processes, 3. reprocessing, and finally 4. redistribution [5]. Green logistics deals also with environmental questions, such as pollution and environmental deg- radation caused by improper logistics processes and utilisation of old and environmentally unfriendly transport technology [6]. Compared to the linear economy alternative, producers will face additional tasks like recovery and secondary material processing. Thus, additionally coordinating a reverse supply chain for the after-use phase of the product requires Reverse Supply Chain Management. This is a totally new approach of Supply Chain Management. [7]

\subsection{European green logistics strategy}

The European green logistics initiative is very strong and very well positioned at macro level. A vast number of different decisions and goals were performed in the last fifteen years. Consequently, environmental issues, tasks and goals are incorporated in the European institutions, enabling EU to give proposals and constantly measure the adoption of proposals in all member states. Moreover, the European green logistics policy made a step forward, with the goal of developing a model of European sustainable logistics. This concept covers three main fields: society, economy and environment, with different activities:

1. Society: safety, health, access, equity.

2. Economy: employment, competitiveness, efficiency, growth, choice.

3. Environment: air quality, noise, land use, biodiversity, waste and climate changes.

The main objective of the European sustainable logistics is to co-ordinate these activities in a way that meets customer requirements and needs at minimum cost. These costs must cover also environmental issues; therefore, it is very important that European companies take more account of the external costs of logistics associated mainly with air quality and pollution, noise, vibration, accidents and climate change. For this reason different research projects are examining ways of reducing these externalities and achieving a more sustainable balance between social, economic and environmental objectives.

\section{NECESSITY FOR GREEN LOGISTICS MODEL SUITABLE FOR SOUTHEAST EUROPE}

The economic situation of Southeast Europe is not as good as in the developed western or northern part of Europe. It can be précised that the entire region is economically underdeveloped, and this affects the transport infrastructure. Many efforts have been invested in highway network development and modernization; meanwhile, the railway infrastructure is old and the need of modernization is more than evident. The same situation is with hinterland terminals, which are just in the function of railway points, and conse- 
quently do not give the needed support as logistics platforms should do.

On the other hand, many privately owned warehouses were built during the last two decades, but they are not in the logistics network function, they just cover local warehousing needs. It is evident that they are in connection with one-way road transport causing many empty return voyages and less ton-km. Issues of pollution, fuel and energy consumption, safety, collecting of waste and utilized transport units are consequently not a prioritized tasks by the industry sector. On the other hand, governments take some actions to set up a green agenda although these actions are not so aggressive and obvious as they should be to stimulate the industry adequately.

\subsection{Setting up green logistics model at macro level}

According to the infrastructure situation and economic situation in Southeast Europe, it is necessary to develop a sustainable model of green logistics that is valid and to be adopted in Southeast Europe. The key elements and goals of modern, lean and green logistics should be considered, and thus a wider range of institutions should be involved directly. Moreover, logistics providers must be the key generators of new ideas and new approaches.

The main reason for particular green model development is in the fact that the railway, ports and hinterland terminals in Southeast Europe are underdeveloped and still state-owned property and therefore under state development policy. The scarcity of state financial funds has huge impacts on infrastructure and suprastructure modernization and consequently road transport is massively used in freight transport sector. This is evident from data collected in Table 1. The road share of inland freight transport, expressed in tonnekilometres, is evidently higher in Southeast European countries than in North European countries. The share in analysed northern countries is around $57 \%$ while in southern countries it is around $80 \%$.

Transportation processes are still based mainly on road transport on traditional West-East transport route between West Europe and Southeast Europe. The connection with Far East trade is done through ports and specialized terminals, where the intermodal inland connections with hinterland terminals practically do not exist. This poses a vast number of challenges on transportation efficiency and network optimization.

The analysed railway infrastructure of some European countries (Table 2) gives a clear picture that Southeast Europe region is not investing in railway development. On the opposite side there are northern European countries, with constant development of national railway system. It is obvious that the railway infrastructure in Southeast Europe must be further developed with new railway connections. In addition, rail transport must be developed as key transport solution between hub terminals, which must be developed and operated as modern logistics platforms. Road transport should be used on shorter routes and for final delivery on door-to-door concept. With this, the southern region of Europe will reach comparable results with northern and western European regions and provide the basis for raising green logistics awareness.

Traffic pollution should be reduced drastically in this way, as road transport accounts for $86 \%$ of $\mathrm{CO}$, $33 \%$ of $\mathrm{CH}$ and $42 \%$ of $\mathrm{NO}_{x}$ from the traffic aspect. Additionally, energy saving is of crucial importance. Namely, road transport accounts for more than $82 \%$ of all energy consumption in the traffic sector. On the other hand, energy consumption of rail transport is lower than $3 \%$ in the traffic sector [9].

Table 1 - Road share of inland freight transport (\% of tonne- $\mathrm{km}$ )

\begin{tabular}{||l|c|c|c|c|c|c|c||}
\hline & 2001 & 2002 & 2003 & 2004 & 2005 & 2006 & 2007 \\
\hline \hline Belgium & 78.3 & 77.5 & 76.5 & 74.9 & 72.4 & 71.1 & 71.1 \\
\hline Germany & 66.5 & 66.3 & 67.0 & 66.1 & 66 & 65.9 & 65.7 \\
\hline Estonia & 31.2 & 30.3 & 29.1 & 32.7 & 35.4 & 34.7 & 43.2 \\
\hline Latvia & 27.4 & 29.2 & 27.5 & 28.4 & 29.8 & 39 & 41.9 \\
\hline Lithuania & 51.7 & 52.3 & 50 & 51.3 & 56.1 & 58.4 & 58.5 \\
\hline Netherlands & 63 & 63.3 & 64.6 & 64.7 & 63.6 & 63.1 & 61.4 \\
\hline Austria & 65.9 & 65.8 & 67.4 & 65.6 & 64.1 & 63.2 & 60.9 \\
\hline Slovenia & 73.0 & 70.0 & 70.0 & 74.1 & 77.3 & 78.2 & 79.2 \\
\hline Croatia & 75.9 & 76.4 & 76.1 & 76.7 & 76 & 74.8 & 74 \\
\hline Macedonia & 87.1 & 92.3 & 93.6 & 92.6 & 91.3 & 93.1 & 88.5 \\
\hline Romania & 49.6 & 57.3 & 62.4 & 60.8 & 67.3 & 70.5 & 71.3 \\
\hline Bulgaria & 60.2 & 62.9 & 61.7 & 66.9 & 70.8 & 69 & 70 \\
\hline Greece & - & - & 97.7 & - & 97.5 & 98.1 & 97.1 \\
\hline \hline
\end{tabular}

Source: Eurostat, 2009 [8] 
Table 2 - Total length of railway lines $(\mathrm{km})$

\begin{tabular}{||l|r|r|r|r|r|r|r|r||}
\hline & 1999 & \multicolumn{1}{|c|}{2000} & \multicolumn{1}{|c|}{2001} & \multicolumn{1}{c|}{2002} & \multicolumn{1}{|c|}{2003} & 2004 & \multicolumn{1}{c|}{2005} & $2005 / 1999$ \\
\hline \hline Belgium & 3,472 & 3,471 & 3,454 & 3,518 & 3,521 & 3,536 & 3,544 & 102.1 \\
\hline Czech Republic & 9,444 & 9,444 & 9,523 & 9,600 & 9,602 & 9,612 & 9,614 & 101.8 \\
\hline Germany & 37,525 & 36,587 & 35,986 & 35,803 & 41,531 & - & 38,206 & 101.8 \\
\hline Sweden & 9,884 & 9,877 & 11,021 & 11,095 & 11,037 & 11,050 & 11,017 & 111.5 \\
\hline Netherlands & 2,808 & 2,802 & 2,809 & 2,806 & 2,811 & 2,811 & 5,231 & 186.3 \\
\hline Slovenia & 1,201 & 1,201 & 1,228 & 1,228 & 1,228 & 1,228 & 1,228 & 102.2 \\
\hline Croatia & 2,726 & 2,726 & 2,726 & 2,726 & 2,726 & 2,726 & 2,726 & 100.0 \\
\hline Macedonia & 699 & 699 & 699 & 699 & - & 699 & 699 & 100.0 \\
\hline Bulgaria & 4,290 & 4,320 & 4,320 & $4,317.7$ & $4,316.2$ & $4,259.2$ & 4,154 & 96.8 \\
\hline Romania & 10,981 & 11,015 & 11,015 & 11,002 & - & 11,053 & 10,948 & 99.7 \\
\hline Greece & 2,299 & 2,385 & 2,377 & 2,383 & 2,414 & 2,449 & 2,576 & 112.0 \\
\hline \hline
\end{tabular}

Source: Eurostat, 2009 [8]

Table 3 - Total greenhouse gas and $\mathrm{CO}_{2}$ emissions from national transport (million tonnes of $\mathrm{CO}_{2}$ equivalent)

\begin{tabular}{|c|c|c|c|c|c|c|c|c|c|c|}
\hline & \multicolumn{5}{|c|}{ Total Greenhouse gas emissions } & \multicolumn{5}{|c|}{ Total $\mathrm{CO}_{2}$ emissions } \\
\hline & 1990 & 2002 & 2003 & 2004 & 2004/1999 & 1990 & 2002 & 2003 & 2004 & $2004 / 1999$ \\
\hline Germany & 164 & 178 & 172 & 173 & $5.10 \%$ & 162 & 176 & 170 & 171 & $5 \%$ \\
\hline Netherlands & 26 & 34 & 35 & 35 & $33.80 \%$ & 26 & 34 & 34 & 35 & $34 \%$ \\
\hline Sweden & 18 & 20 & 20 & 20 & $9.00 \%$ & 18 & 19 & 20 & 20 & $9 \%$ \\
\hline Belgium & 20 & 26 & 26 & 27 & $34.00 \%$ & 20 & 25 & 25 & 26 & $33 \%$ \\
\hline Denmark & 11 & 13 & 13 & 13 & $26.80 \%$ & 10 & 12 & 12 & 13 & $24 \%$ \\
\hline Slovenia & 3 & 4 & 4 & 4 & $57.30 \%$ & 3 & 4 & 4 & 4 & $54 \%$ \\
\hline Croatia & 4 & 5 & 5 & 5 & $34.90 \%$ & 4 & 5 & 5 & 5 & $31 \%$ \\
\hline Romania & 9 & 12 & 12 & 17 & $95.20 \%$ & 9 & 12 & 12 & 17 & $95 \%$ \\
\hline Bulgaria & 11 & 6 & 7 & 7 & $-32.10 \%$ & 11 & 6 & 7 & 7 & $-32 \%$ \\
\hline Greece & 16 & 21 & 22 & 22 & $42.60 \%$ & 15 & 20 & 21 & 22 & $41 \%$ \\
\hline
\end{tabular}

Source: European Environment Agency, 2006 [10]

According to data analysed in Table 3 the countries of Southeast Europe registered higher increase of greenhouse and $\mathrm{CO}_{2}$ emissions in the last fifteen years. This is directly connected with the rail transport use, as northern countries shift a lot of freight transport from road to rail transport.

Intermodal transportation is an obvious option because it is possible to increase rail transport utilization and at the same time the intermodal units are very easy to handle and consequently they generate savings in cargo manipulation. Thus, cargo safety is set at a higher level, and consequently, damages on cargo and packaging material can be reduced drastically. By using intermodal units (containers), the modal shift is easier to perform within a shorter time.

Efforts in network optimization should be focused also on the manufacturing industry. Companies must optimally redesign their manufacturing processes and distribution networks. Logistics providers are therefore forced to enter the market of Southeast Europe as 4PL providers, where today they are just organizing transportation of materials and final products in most cases.

In this context, a macro model is proposed with five main fields of development, on which the logistics sector of Southeast Europe should be focused in the future. It is an extended model based on Stoke and Aimi's proposal for cooperation between companies and logistics providers. [11] These fields are:

- Efficient transportation and modal shift;

- Network optimization;

- Transport units and packaging materials;

- Greener facilities and operations;

- Recycling operations.

Governments and the entire industry of Southeast Europe must take an active part to set up and adopt macro strategies in all five fields. It is up to governments to develop a single intermodal network, with intermodal terminals in important economy basins. On the other hand, it is up to the manufacturing industry and logistics providers to use adequate transport units and packaging materials, to build greener facilities and stimulate recycling operations. 


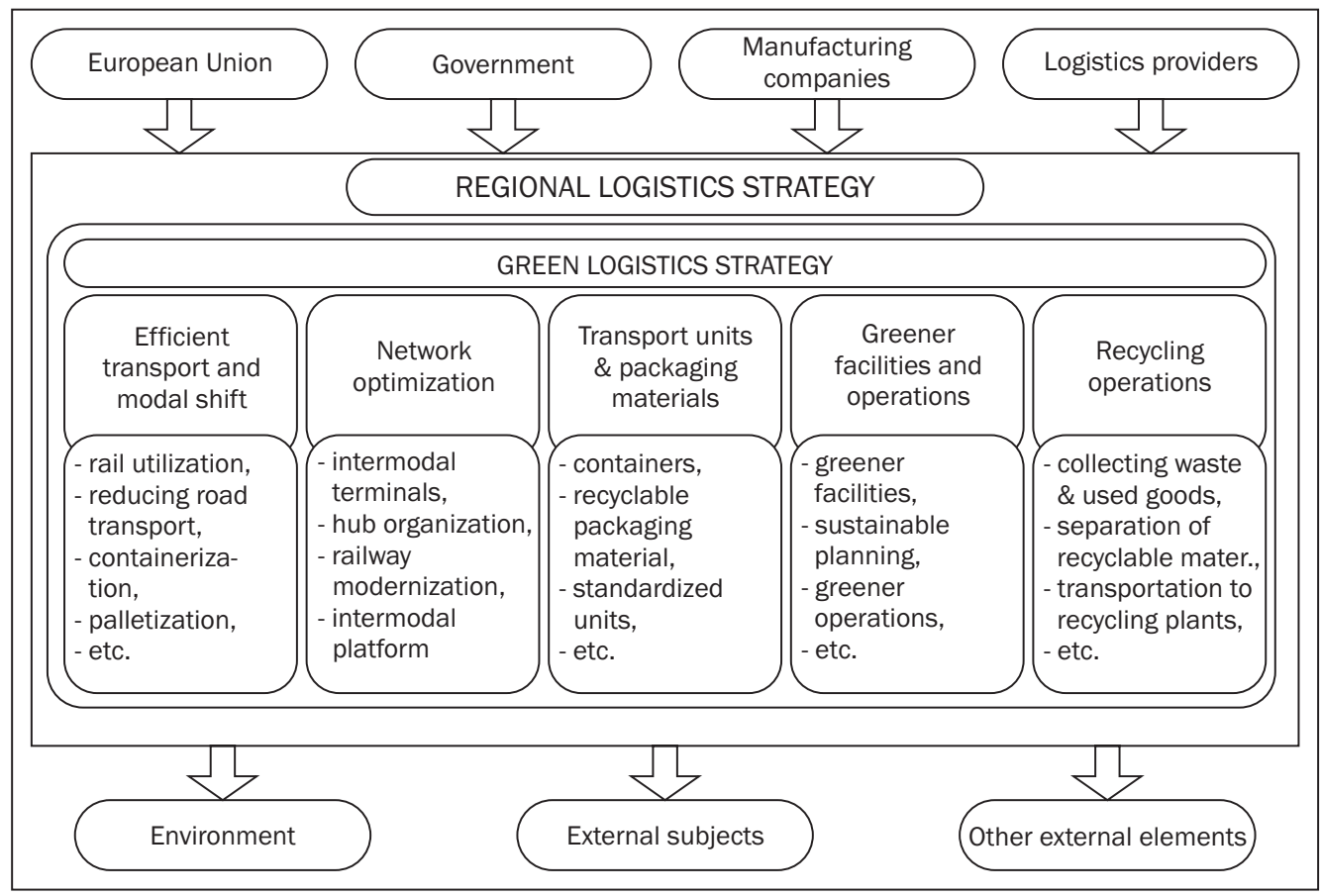

Figure 1 - Macro model for green logistics implementation in SE Europe

Greener facilities include all aspects of environmental protection. A sustainable site plan of logistics facilities is important and should be coordinated with international hub transport network concept. Pan-European corridors in Southeast Europe should be used as the first reference and economy basins as the second one. On the other hand, all these facilities (closed and open warehouses, terminals, etc.) must produce water and energy savings, reduce light and noise pollution and develop processes for material selection. Greener operations must be developed and used in daily working processes. Additionally, environmental quality standard should be set up and constantly measured.

The last field of recycling operations is an important part of green logistics. The European Directives on packaging and packaging waste, end-of-life vehicles and electrical and electronic waste have raised the profile of waste as an issue and led to the creation of recycling solutions that would not otherwise have existed. In addition, producer responsibility has had a positive impact upon the way products are designed. By placing the costs of recycling principally with producers, it encourages them to design their products differently to make recycling easier and therefore less expensive. [12] Logistics providers can help them in developing a harmonised network and operations. The use of recycled materials for packaging materials and avoiding plastics is an important issue for every company, especially in the Southeast Europe where the perception of green logistics is still in the evolution phase.

\subsection{Development of green logistics at micro level}

All the aspects of environmental outcomes are nowadays an important part of development strategy in all important companies. It has become very difficult for them to deny the direct connection between corporate actions and environmental issues, especially in regions where macro green logistics is already in force.

Consequently, the pressure to manage a green supply chain is stronger than ever before. From collecting just the waste and used transport units that are operations, which were managed at the end of logistics operations, we came to an era when the entire logistics within the manufacturing company and in the entire logistics process must be managed as green logistics. Moreover, the green concept of managing logistics must start with the use of recycled materials in production and ecological transport means. This way, the final product will be easier to recycle with less energy and in shorter time [13].

All companies in Southeast Europe will be forced to incorporate green logistics concept eventually. It is important that companies overtake national or international regulations; they must introduce ecological considerations in every step of their business processes. Of course, they must remain lean, and lean thinking must be used in the development of green logistics as well. 


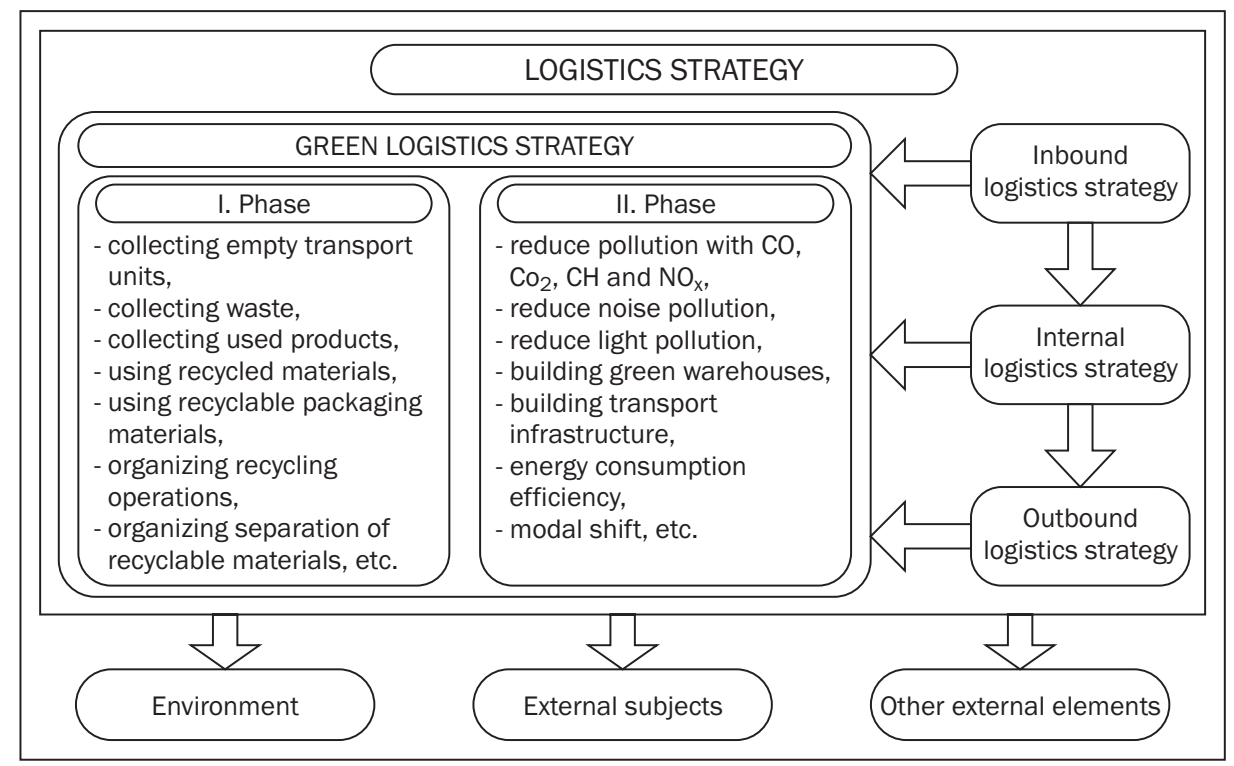

Figure 2 - A model of green logistics elements diversification

In connection with our macro model of green logistics implementation, the proposal is to set up an adequate two-pillar system of green logistics at micro level - in every company. The first pillar should include actions which have direct bearing on production, and with it collecting of waste materials, used products, empty transport units should be organized as the first step. The second step should have as a goal the separation of recycled materials and organization of processes for recycling operations. These activities do not need large investments, but are subject to an adequate micro re-organization.

The second pillar is based on the future development and vision of a company, and importantly, depends on the national transport and environmental strategy. Thus, it is in direct relation with intensive investments and government transport infrastructure development strategy. Actions have been included which have deep impact on the strategy and future position of a company on the market. Elements as pollution with greenhouse gas, noise and light pollution are the first group elements. In the second group are those elements, which have impacts on environmental degradation. These are logistics facilities, such as warehouses and logistics terminals, and transport infrastructure, such as roads, highways, bridges, railways, etc.

All the mentioned elements of the proposed model should be part of the widest strategy of each company. Specialized logistics service providers should be involved in the preparation of green strategy, as diversified elements of logistics must be adequately included. An adequate strategy at micro level will stimulate governmental institutions to take necessary actions in active development of green environment policy.

\subsection{Implementation of regulations in regional and national environment}

It is of vital importance that all the logistics sectors identify themselves in macro and micro models; otherwise, they will continue to offer just low cost service, with no emphasis on green logistics. It is an advantage that some companies have already implemented green logistics in their corporate strategies, so they are not waiting for actions and instructions by the government. This is the so-called bottom-up concept, where the industry recognizes the need and benefits of green strategies implementation. Of course, logistics companies firstly implement soft elements, described as the first pillar in our model. The use of recycled materials and organized waste collecting and recycling is a very good marketing step, as consumer understands and approves such actions. Moreover, these actions do not impose high financial investments and do not increase the total costs drastically.

The bottom-up approach must become the industry preference, as it is possible to develop industryfriendly directions. Thus, companies can enter in the sector of pollution, environment degradation and efficient use of means of transport. With their coordinated actions, it is possible to cooperate with governmental institutions and to have a possibility to influence a macro model development - to influence future legislation and governmental intervention in the logistics sector.

If strong interests to set up the bottom-up model in Southeast Europe do not exist, and this is very often valid for the underdeveloped regions, then the topdown model appears inevitable. A macro model must be set up firstly. This model consists of governmental actions in the field of legislation and environmental 
policy. The first steps consist of green agenda, in order to cover environmental issues and to have an extensive view on national environmental policy. The next steps are the pricing policy and legislation; to distribute and collect funds to cover external costs; and to set as mandatory the collection and recycling of products and transport units, and to control movements of hazardous goods. The government can pose other issues, as safety regulations, land disruptions restrictions, education measures, etc.

It is of vital importance for logistics industry of Southeast Europe to establish the bottom-up model in order to participate in developing of national environmental and green logistics policy. All parties - the industry and logistics providers - must put forward a strategy to develop a micro level model, where the green elements will be placed in different sectors of their presence. Thus, they will be active partners to the government and will have the influence on future legislation and everyday working rules. It must become a necessity of modern logistics concept for Southeast Europe, in order to set up a moderate model of supply chain management.

\subsection{Involving logistics providers in green logistics}

The entire industry must see the benefits of implementing green logistics as corporate strategy. For the time being, it is very difficult for the manufacturing industry to establish all the key elements of green logistics in their business environment. Some steps have been undertaken in the last ten years, but mostly in the segment of pollution with utilization of ecologically friendly transport means. Some of them are entering the segment of collecting used and refused goods. Certainly, this is not enough to follow the high standard of green logistics posed by the developed regions.

The question of absorbing the additional costs is an important element and very actual in Southeast Europe. The industry and end users very often refuse them. Therefore, it is hardly believable that logistics providers will absorb them so easily. For this reason, long-term contracts, for three to five years of cooperation, are very important for logistics providers. Such cooperation would enable logistics providers to absorb some of the start-up green logistics costs. The partnership cannot be set up just on goods transportation but in a wider context - to organize and manage logistics operations. Regretfully, this has not been in practice in transport and logistics industry so far, because the production companies manage their internal, and some, external logistics by themselves. On the other hand, logistics operators offer warehouse facilities and pure point-to-point transport with still strong emphasis on customs formalities.
Obviously, big challenges in the development of green logistics exist in the region of Southeast Europe. The fundamental basis for green logistics development, as infrastructure and network organization, is insufficiently developed. Consequently, the industry is not motivated to develop green logistics concepts. For this reason, logistics providers must take a guiding position in order to promote and require green initiatives. Therefore, there is a need to promote and develop a regional approach of green logistics. This can be done with active cooperation between industry, logistics sector and government institutions.

\section{OBSTACLES IN GREEN LOGISTICS MODEL DEVELOPMENT}

Different models of green logistics have been already developed and incorporated in many different global companies. All of them had and still have a unique goal - to do business on environmentally friendly base. However, in reality, new concepts of supply chain management have introduced a lot of doubtful actions and strategies, which do not appear to be environmentally friendly and in harmony with the green logistic concept. This causes resistance of manufacturing and logistics industry in the development and adoption of green models, at micro and macro industry levels. This is also present in the region of Southeast Europe, where costs, time and flexibility have priority over environmental objectives.

New logistics trends, especially in the era of economical crisis, accentuate fast delivery within developed network and less use of warehousing operations. Consequently, all markets all over the globe already use the same priorities in everyday logistics operations nowadays. Those priorities are based on key elements such as:

- Costs - to reduce them as much as possible in production and transport operations,

- Time and flexibility - to produce operations on justin-time concept and to introduce lean concepts in production and transportation,

- Reliability - to offer time based concepts without damages or cargo losses,

- Network concept - to organize massive transport flows between hub logistics platforms and capillary distribution up to final users,

- Infrastructure with adequate logistics terminals and warehouses at main regional and local points.

The issue of costs is an important element in the Southeast Europe economy. The pressure of cost savings is becoming stronger and stronger, and this is more than evident in the logistics sector, which is understandable and logical from the economic point of view. However, the paradox of cost savings is in limited acceptance of external costs. National governments 
cover a greater part of infrastructure and suprastructure provisions, congestion and pollution costs and safety issues, despite the fact that those external costs belong to the logistics sector. With increasing transport activities and logistics operations the pressure is bigger, but logistics aspires to not to absorb them in the greater part, in order to be cost-effective on the market.

Time and flexibility are essential components of modern logistics and this is valid also for Southeast Europe industry. The time reduction can be achieved by increased speed. Consequently, the pollution and energy consumption is increasing drastically. In this context, logistic providers use door-to-door and justin-time strategies in order to be flexible and lean as much as possible. Nevertheless, with these strategies and actions the pressure to use road transport is increasing, because it is possible to reach each final point without additional manipulations. Moreover, the underdeveloped railway infrastructure stimulates such approach. Therefore, the total tonne-km of freight transported by road is increasing drastically. The more the time and flexibility strategies are applied, the more the negative environmental consequences of the logistics increase.

Reliability is an important logistics element for clients. They want a service without damages on their cargo and within agreed total transit time; therefore, they make pressure on the logistics providers to prefer reliable services. In general, sea and rail transport generate much more cargo damages and deviation on the agreed transit time, and consequently, logistics providers prefer road and air transport. The latter ones are the two least environmentally friendly modes.

The network concept and infrastructure issues are two important parts of modern logistics models. In order to develop a network model with hub points and distribution services, proper infrastructure must be built. As much as hub terminals with spread road network are built, the concentration of environmental impacts increases. The second point of infrastructure paradox in the logistics is the issue of warehouse usage. To be lean, the stockpile must be managed at the minimum level. Consequently, the goods are transferred to transport sector, with direct deliveries causing environmentally adverse impacts [14].

Obviously, big challenges in the development of green logistics exist in the region of Southeast Europe. To some extent, the industry is not motivated to develop green logistics concepts. Therefore, there is need to promote and develop a regional approach of green logistics. This can be done with active cooperation be- tween industry, logistics sector and government institutions. All these parties should be motivated to develop a sustainable green logistics model; therefore, further researches and proposals are very important to reach this essential goal.

\section{CONCLUSION}

Modern logistics and supply chain management entered into a new era of logistics evolution. This is evident in the developed regions for more than two decades already. Different studies and analyses were produced, and some global enterprises already incorporated green elements and green logistics in their corporate strategy and vision. The situation in Southeast Europe is far away from such a perception. The infrastructure and suprastructure do not fulfil high international environmental standards, and consequently not all the regional parties from manufacturing industry and logistics sector are motivated to develop and adopt green logistics concepts.

It is more than evident that a regional approach, with long-term perspective, must be developed. The proposed models of establishing green concepts are the initial basis for setting up an appropriate model for Southeast Europe. All national governments must reach a consensus how to develop a unique intermodal network with specialized intermodal platforms in the biggest economic basins. Moreover, administrative procedures as customs and other inspections should be simplified and made uniformed. Thus, the railway utilization should increase and some key elements of green logistics (e.g. pollution, energy savings, environmental disruption etc.) should be fulfilled immediately.

Recycling initiatives are the second most important aspect of green logistics development in the region. Manufacturing companies should be stimulated to use recyclable material as production material and for packaging materials. Governments should adopt reduced taxes for the companies, or unburden them from external costs, deriving from environmental issues. On the other hand, other companies should take greater share of external costs in order to stimulate them to think green.

With this paper, a step has been made toward the integration of green logistics in the development of supply chain management in Southeast Europe. Some initial and important development steps must be done in the coming period, enabling the environmental management systems, such as ISO 14000 , and offer opportunities to greener logistics industry in Southeast Europe. 


\section{Dr. BOJAN BEŠKOVNIK}

E-mail: bojan.beskovnik@intereuropa.si

Intereuropa, Globalni logistični servis, d.d.

Vojkovo nabrežje 32, 6000 Koper, Republika Slovenija

Prof. dr. LIVIO JAKOMIN

E-mail: livio.jakomin@gmail.com

Strma pot 11, 6320 Portorož, Republika Slovenija

\section{POVZETEK}

\section{IZZIVI ZELENE LOGISTIKE V JUGOVZHODNI EVROPI}

Članek opisuje trende $v$ zeleni logistiki z globalnega vidika in izzive pri vzpostavitvi zelene logistike $v$ regiji jugovzhodne Evrope. Moderna logistika s konceptom oskrbovalnih verig doživlja obdobje pomembnih sprememb. Od reverzibilne logistike smo prišli do zelene logistike, ki je širši koncept prijaznejšega obravnavanja okolja. Reverzibilna logistika vsebuje procese premikanja in prevoza odpadkov od uporabnikov do obratov za recikliranje, medtem ko se zelena logistika ukvarja tudi z okoljskimi vprašanji, kot so onesnaževanje in degradacija okolja, povzročenih z neprimernimi logističnimi procesi in uporabo stare ter okolju neprijazne transportne tehnologije. $V$ naši raziskavi je bil analiziran primer jugovzhodne Evrope ter $v$ tem kontekstu tudi podan predlog izvedbe razvojnega modela zelene logistike. Še vedno je $v$ tej regiji prisotnih veliko različnih izzivov, tako morajo biti sistematične analize in predlogi predmet dodatnega znanstvenega dela $v$ logističnem sektorju. Vsi sodelujoči, vključujoč proizvodno industrijo, logistična podjetja in vlade posameznih držav morajo aktivno sodelovati $v$ takšnih raziskavah, saj bo pritisk zelenega razmišljanja postal vse močnejši v prihajajočem obdobju.

\section{KLUČNE BESEDE}

reverzibilna logistika, zelena logistika, logistiki, jugovzhodna Evropa, model zelene logistike

\section{LITERATURE}

[1] BearingPoint: Survey report, How mature is the Green Supply Chain?, BearingPoint, Dallas, USA, 2008
[2] Simchi-Levi, D.: Going green in the supply chain, Manufacturing \& logistics IT, IBC, Hertfordshire, England, 2008

[3] Tanja P.T.: A decrease in energy use by logistics: a realistic opportunity?, European Conference of Ministers of Transport: Freight Transport and the Environment, Brussels, Belgium, 1991, pp. 151-165

[4] Murphy, P., Poist, R. F., Braunschweig, C. D.: Management of Environmental Issues in Logistics: current status and future potential. Transportation Journal, 1994, pp. $48-56$

[5] de Brito, M. P., Dekker, R.: A framework for reverse logistics, Reverse logistics - Quantitative Models for Closed-Loop Supply Chains, Springer, Berlin, 2004, pp. 3-29

[6] Blumberg, D. F.: Reverse logistics and closed loop supply chain processes, Taylor \& Francis, New York, 2004

[7] Schultmann, F., Zumkeller, M., Rentz, O.: Integrating Spent Product's Material into Supply Chains: The Recycling of End-of-Life Vehicles as an Example, Supply Chain Management and Reverse Logistics, Springer, Berlin, 2003

[8] http://epp.eurostat.ec.europa.eu/portal/page/portal/ transport/data/main_tables

[9] Nikolić, S., Lazić, D.: Zelena logistika - Green logistics. 1. Nacionalna konferencija o kvalitetu života, Festival kvaliteta 2006, Kragujevac, Serbia, 2006

[10] Rigler, E., Kampel, E.: Transport emissions of greenhouse gases, European Environment Agency, Copenhagen, Denmark, 2006

[11] Stoke, S., Aimi, G.: The green logistics factor, Inside supply management, Vol. 20, No. 4, 2009, p. 34

[12] Bouhlal, A.: Green logistics, $9^{\text {th }}$ International Conference on Traffic Science ICTS 2005, Portorož, Slovenia, November 2005

[13] European Commission, EU Waste policy - The story behind the policy, Brussels, 2007.

[14] Rodrigue, J. P., Slack, B., Comtois, C.: Green Logistics (The Paradoxes of), The handbook of Logistics and supply-chain management, Handbooks in transport, No. 2, London, 2001 